\begin{tabular}{lllllllllllllllll}
$\mathrm{S}$ & $\mathrm{T}$ & $\mathrm{U}$ & $\mathrm{D}$ & $\mathrm{I}$ & $\mathrm{A}$ & & $\mathrm{T}$ & $\mathrm{E}$ & $\mathrm{M}$ & $\mathrm{A}$ & $\mathrm{T}$ & $\mathrm{Y}$ & $\mathrm{C}$ & $\mathrm{Z}$ & $\mathrm{N}$ & $\mathrm{E}$ \\
\hline
\end{tabular}

STUDIA Z PRAWA WYZNANIOWEGO

Tom $21-2018$

DOI: https://doi.org/10.31743/spw.194

MICHAŁ OŻÓG*

\title{
CHARAKTERYSTYKA STOSUNKU PRAWNEGO ŁĄCZĄCEGO KAPELANA Z PODMIOTEM LECZNICZYM W ŚWIETLE PRZEPISÓW PRAWA POLSKIEGO I WYBRANYCH REGULACJI PRAWA WEWNĘTRZNEGO KOŚCIOŁA KATOLICKIEGO
}

\author{
Streszczenie
}

Przedmiotem artykułu jest przedstawienie form prawnych nawiązania współpracy podmiotu leczniczego $\mathrm{z}$ kapelanem $\mathrm{w}$ celu zagwarantowania pacjentom prawa do opieki duszpasterskiej. Problem badawczy stanowi określenie relacji prawnej łączącej kapelana z placówką medyczną, w której pełni posługę. Celem badań było scharakteryzowanie stosunku prawnego łączącego kapelana z podmiotem leczniczym z uwzględnieniem form: umowy o pracę, umowy zlecenia oraz umowy o świadczenie wolontariatu. Główną metodę badawczą stanowi metoda dogmatyczna oraz w uzupełniającym zakresie metoda historyczna. Wyniki badań prowadzą do wniosku o szczególnym znaczeniu umowy o pracę dla ukształtowania więzi prawnej kapelana z podmiotem leczniczym. Stosunek prawny łączący kapelana z podmiotem leczniczym ma charakter ramowy na gruncie prawa państwowego z uwagi na konieczność poszanowania relacji instytucjonalnych między państwem a kościołami i innymi związkami wyznaniowymi. Szczegółowe obowiązki duchownego określa prawo wspólnoty religijnej, z której duchowny się wywodzi, jednakże nie obowiązuje ono automatycznie na forum prawa państwowego.

Słowa kluczowe: kapelan; kościoły i inne związki wyznaniowe; pacjent; posługa duszpasterska; wolność sumienia i religii

$* * * * *$

* Mgr, doktorant w Zakładzie Prawa Kościelnego i Wyznaniowego, Wydział Prawa i Administracji, Uniwersytet Jagielloński, ul. Gołębia 9, 31-007 Kraków; student Wydziału Prawa Kanonicznego UPJP2; e-mail: michal.ozog@doctoral.uj.edu.pl. ORCID 0000-0002$4315-5235$ 


\section{UWAGI OGÓLNE}

Artykuł 53 ust. 2 zd. 2 in fine Konstytucji zapewnia ,,prawo osób do korzystania z pomocy religijnej, tam gdzie się znajdują"1. Gwarancje prawne duszpasterstwa w podmiotach leczniczych zawarte są w aktach prawnych z różnych szczebli hierarchii źródeł prawa ${ }^{2}$. Prawo do opieki duszpasterskiej stanowi prawo pacjenta, które uregulowane zostało w art. 36-38 ustawy z dnia 6 listopada 2008 r. o prawach pacjenta i Rzeczniku Praw Pacjen$\mathrm{ta}^{3}$, a także w dwunastu ustawach indywidualnych określających stosunek państwa polskiego do poszczególnych kościołów i innych związków wyznaniowych. Wymienione powyżej akty normatywne zawierają przepisy prawne kształtujące status: beneficjentów prawa do opieki duszpasterskiej; wspólnot religijnych, organizujących duszpasterstwo specjalne w podmiotach leczniczych, a także osób duchownych, pełniących posługę wobec pacjentów. Nie bez znaczenia pozostaje również ukształtowanie pozycji prawnej podmiotów leczniczych, które odpowiadają za zagwarantowanie prawa do opieki duszpasterskiej.

Przedmiotem niniejszego opracowania jest przedstawienie statusu kapelanów w podmiotach leczniczych w perspektywie stosunku prawnego łączącego duchownego z placówką leczniczą. Opracowanie zawiera próbę określenia położenia prawnego duchownego z punktu widzenia ram prawnych jego współpracy z podmiotem leczniczym. W literaturze przedmiotu w ograniczonym zakresie podejmowano tę problematykę ${ }^{4}$. Rozważania w tym zakresie wymagają analizy norm z różnych gałęzi prawa. Na status duchownego wpływają bowiem ogólne normy prawne zapewniające swobodne wypełnianie funkcji religijnych przez kościoły i inne związki wyznaniowe, a ponadto uregulowania wyznaczające obowiązki podmiotów leczniczych w zakresie stworzenia warunków organizacyjnych dla realizacji prawa do opieki duszpasterskiej. Zakres uprawnień duchownego w obszarze duszpasterstwa specjalnego w podmiotach leczniczych może być zróżnicowany z uwagi na położenie prawne wspólnoty religij-

\footnotetext{
Dz.U. z 1997 r. Nr 78, poz. 483 z późn. zm., dalej: Konstytucja.

Zarzycki 2014, 84.

Tekst jedn. Dz.U. z 2017 r., poz. 1318, dalej: u.p.p.R.P.

4 Stanisz 2016, 322-325.
} 
nej. Dotyczy to przede wszystkim możliwości zatrudnienia duchownego z uwzględnieniem różnych form przewidzianych w prawie państwowym, które mogą być wykorzystane do stworzenia ram prawnych dla pełnienia tej posługi. Kwestią do rozważania pozostaje również scharakteryzowanie położenia prawnego duchownego, pełniącego funkcję kapelana w podmiocie leczniczym w sposób niesformalizowany. Normy prawne wyznaczające obowiązki podmiotu leczniczego mogą istotnie determinować politykę kadrową kierownictwa podmiotów leczniczych w zakresie współpracy z duchownymi. Należy uwzględnić również przepisy prawa pracy, prawa cywilnego, w zakresie w jakim stanowią one podstawę prawną ukształtowania stosunku prawnego łączącego duchownego z podmiotem leczniczym.

W tekście występują również odniesienia do wybranych regulacji wewnętrznych Kościoła Katolickiego. Należy bowiem zauważyć, że z jednej strony duchowny, pełniąc swoją posługę podlega prawu państwowemu, z drugiej zaś prawu wewnętrznemu wspólnoty religijnej, której jest członkiem. Prawo kościelne przewiduje bowiem szereg uregulowań wyznaczających status kapelana szpitalnego w relacji do placówki, do której jest kierowany oraz wobec wspólnoty religijnej, z której się wywodzi. Ze względu na zasadę autonomii porządków prawnych (art. 25 ust. 3 Konstytucji) nie można uznać tych norm za powszechnie obowiązujące na forum świeckiego porządku prawnego, aczkolwiek warto ocenić ich treść z punktu widzenia uregulowań dotyczących preferowanego modelu stosunku prawnego.

Za podjęciem tytułowej tematyki przemawiają walory praktyczne, ponieważ sposób ukształtowania statusu duchownego realnie wpływa na zagwarantowanie prawa do opieki duszpasterskiej pacjentom w poszczególnych placówkach ochrony zdrowia. Stopień związania duchownego z podmiotem leczniczym kształtuje jego dostępność dla chorych, a jest to szczególnie ważne, gdyż organizuje i wykonuje zbiorowe praktyki religijne w kaplicy szpitalnej, sprawuje sakramenty, podejmuje rozmowy duszpasterskie, itd. Warto zatem scharakteryzować zastosowanie występujących możliwości prawnych ukształtowania statusu kapelana pełniącego posługę $\mathrm{w}$ podmiotach leczniczych $\mathrm{w}$ perspektywie realizacji zakładanego celu, a więc zagwarantowania pacjentom prawa do opieki duszpasterskiej. 


\section{TERMIN „KAPELAN”W WYBRANYCH AKTACH PRAWNYCH}

W pierwszej kolejności należy przedstawić znaczenie terminu kapelan. Warto zauważyć, że kapelan, to wyrażenie języka potocznego, a także prawnego. W ujęciu etymologicznym kapelan jest to (1) „ksiądz katolicki pełniący rolę duszpasterza określonej grupy osób, np. w wojsku, zakładzie wychowawczym, więzieniu itp.; (2) kapłan usługujący innemu kapłanowi"s. Zacytowana powyżej definicja słownikowa ogranicza znaczenie wyrazu kapelan do jednej wspólnoty religijnej, aczkolwiek na gruncie prawodawstwa jednoznacznie trzeba przyjąć, że termin ten odnosi się do duchownych różnych wyznań. Do takiego wniosku prowadzi fakt jego występowania w dwunastu ustawach indywidualnych określających położenie prawne: Kościoła Katolickiego ${ }^{6}$, Polskiego Autokefalicznego Kościoła Prawosławnego ${ }^{7}$, Kościoła Ewangelicko-Augsburskiego ${ }^{8}$, Kościoła Polskokatolickiego ${ }^{9}$, Starokatolickiego Kościoła Mariawitów ${ }^{10}$, Kościoła Zielonoświątkowego ${ }^{11}$, Kościoła Adwentystów Dnia Siódmego ${ }^{12}$, Kościoła Chrześcijan Baptystów ${ }^{13}$, Kościoła Ewangelicko-Metodystycznego ${ }^{14}$, Kościoła Katolickiego Mariawitów ${ }^{15}$, Gmin Wyznaniowych Żydowskich $^{16}$, Kościoła Ewangelicko-Reformowanego ${ }^{17}$. Art. 17 ust. 3 Konkordatu między Stolicą Apostolską i Rzecząpospolitą Polską z dnia 28 lipca 1993 r. ${ }^{18}$ również wymienia kapelana w kontekście posługi w podmiotach leczniczych według ówczesnej terminologii stosowanej na oznaczenie jednostek organizacyjnych wykonujących zadania w zakresie ochrony zdro-

\footnotetext{
5 Https://sjp.pl/kapelan [dostęp: 29.11.2017].

Tekst jedn. Dz.U. z 2013 r., poz. 1169.

7 Tekst jedn. Dz.U. z 2014 r., poz. 1726.

8 Tekst jedn. Dz.U. z 2015 r., poz. 43.

9 Tekst jedn. Dz.U. z 2014 r., poz. 1599.

10 Tekst jedn. Dz.U. z 2015 r., poz. 14.

11 Tekst jedn. Dz.U. z 2015 r., poz. 13.

12 Tekst jedn. Dz.U. z 2014 r., poz. 1889.

13 Tekst jedn. Dz.U. z 2015 r., poz. 169.

14 Tekst jedn. Dz.U. z 2014 r., poz. 1712.

15 Tekst jedn. Dz.U. z 2014 r., poz. 44.

16 Tekst jedn. Dz.U. z 2014 r., poz. 1798.

17 Tekst jedn. Dz.U. z 2015 r., poz. 483.

18 Dz.U. z 1998 r. Nr 51 poz. 318.
} 
wia. Analiza kontekstu, w jakim stosuje się termin „kapelan” w ustawach indywidualnych skłania do konstatacji, iż zdecydowanie częściej używany jest on do określenia duchownego pełniącego funkcję w Wojsku Polskim niż w podmiotach leczniczych. Zasadniczo jedynie w aktach prawnych dotyczących: Kościoła Katolickiego, Polskiego Autokefalicznego Kościoła Prawosławnego, Kościoła Polskokatolickiego, Kościoła Adwentystów Dnia Siódmego, Kościoła Ewangelicko-Metodystycznego mowa jest wprost o kapelanie również w odniesieniu do sprawowania duszpasterstwa w podmiotach leczniczych.

Pojęcie „kapelan” nie występuje w ustawach indywidualnych sprzed II wojny światowej, które nadal obowiązują i określają status prawny: Muzułmańskiego Związku Religijnego w Rzeczypospolitej Polskiej ${ }^{19}$, Karaimskiego Związku Religijnego ${ }^{20}$, Wschodniego Kościoła Staroobrzędowego nieposiadającego hierarchii duchownej ${ }^{21}$. W aktach tych nie znajdziemy również regulacji dotyczącej gwarancji wolności sumienia i religii w podmiotach leczniczych. Nie oznacza to jednak braku ustawowych podstaw prawnych dla realizacji wolności z art. 53 Konstytucji w obszarze podmiotów leczniczych. Powyższe wspólnoty religijne oraz ich wierni mogą bowiem wywodzić swoje prawa w tym zakresie z innych aktów prawnych, w tym z ustawy z dnia 17 maja 1989 r. o gwarancjach wolności sumienia i wyznania ${ }^{22}$.

Termin „kapelan” występuje w rozporządzeniu Ministra Zdrowia z dnia 17 lipca 2014 r. w sprawie warunków wynagradzania za pracę pracowników podmiotów leczniczych działających w formie jednostki budżetowej ${ }^{23}$. Akt ten wymienia „kapelana szpitalnego” w kategorii stanowisk „pracownicy wykonujący zawód medyczny oraz inni pracownicy, których praca pozostaje w związku z udzielaniem świadczeń zdrowotnych”. Na szczególne podkreślenie zasługuje fakt, że akt ten nie zawęża określenia „kapelan szpitalny” do jakiejkolwiek wspólnoty religijnej, z czego można wnioskować, że prawodawca dopuszcza ustanowienie wynagrodzenia za

19 Dz.U. z 1936 r. Nr 30, poz. 240 z późn. zm.

20 Dz.U. z 1936 r. Nr 30, poz. 241 z późn. zm.

21 Dz.U. z 1928 r. Nr 38, poz. 363 z późn. zm.

22 Tekst jedn. Dz.U. z 2017 r., poz. 1153, dalej: u.g.w.s.w.

23 Tekst jedn. Dz.U. z 2017 r., poz. 304, dalej: rozporządzenie. 
posługę sprawowaną w podmiotach leczniczych przez duchownych różnych wyznań, o czym szerzej w dalszej części tekstu.

\section{DOPUSZCZALNOŚĆ ZATRUDNIANIA KAPELANÓW W PODMIOTACH LECZNICZYCH}

Podejmując problematykę stosunku prawnego łączącego kapelana z podmiotem leczniczym, należy stwierdzić, że podmioty lecznicze nie mają obowiązku zatrudniać kapelanów ${ }^{24}$. Zgodnie z art. 36 ustawy z dnia 6 listopada 2008 r. o prawach pacjenta i Rzeczniku Praw Pacjenta podmiot leczniczy wykonujący działalność leczniczą w rodzaju stacjonarne i całodobowe świadczenia zdrowotne ma obowiązek zapewnić pacjentom prawo do opieki duszpasterskiej. Przepis ten nie nakłada jednak obowiązku nawiązania stosunku pracy z duchownym. Sprawy techniczno-organizacyjne związane z realizacją duszpasterstwa pozostawione zostały do ukształtowania podmiotom leczniczym. W związku z tym w systemie podmiotów leczniczych występuje bogata mozaika rozwiązań prawnych w zakresie ukształtowania modelu współpracy kapelanów z podmiotami leczniczymi. Warto jednak zauważyć, że dopuszczalność zatrudniania duchownych na etacie przewidują wprost tylko regulacje prawne dotyczące Kościoła Katolickiego oraz Polskiego Autokefalicznego Kościoła Prawosławnego. Istniejący stan prawny wywołuje w tym zakresie wątpliwości z punktu widzenia zasady równouprawnienia kościołów i innych związków wyznaniowych, która wyrażona została w art. 25 ust. 1 Konstytucji ${ }^{25}$.

Zasadnicze pytanie dotyczy zatem dopuszczalności zatrudniania duchownych innych wyznań. W pierwszej kolejności należy stwierdzić, że w świetle art. 38 u.p.p.R.P. koszty realizacji prawa do opieki duszpasterskiej (art. 36 u.p.p.R.P.) oraz prawa do kontaktu z duchownym w razie pogorszenia się stanu zdrowia lub zagrożenia życia (art. 37 u.p.p.R.P.) ponosi podmiot leczniczy, chyba że przepisy odrębne stanowią inaczej. Mając powyższe na uwadze trzeba wyróżnić prawo kościoła i innego związku

24 Autor zwracał na to uwagę w opracowaniu: Ożóg 2018, 61 i n. Niniejszy tekst nawiązuje do poczynionych ustaleń.

25 Ożóg 2016, 223 i n. 
wyznaniowego do prowadzenia duszpasterstwa specjalnego w podmiocie leczniczym w formie zinstytucjonalizowanej (na podstawie umowy) oraz niezinstytucjonalizowanej (faktyczna działalność osób duchownych w podmiocie leczniczym $)^{26}$. Pierwsza forma powinna dotyczyć kościołów i innych związków wyznaniowych o uregulowanej sytuacji prawnej. Wydaje się zasadne przyjęcie, że możliwość zatrudniania duchownych w publicznych podmiotach leczniczych dotyczyć będzie tylko kościołów i innych związków wyznaniowych o statusie prawnym uregulowanym według polskiego porządku prawnego, a więc w drodze umowy międzynarodowej (art. 25 ust. 4 Konstytucji), ustawy lub decyzji administracyjnej i rozporządzenia Prezydenta RP (dotyczy jedynie Wschodniego Kościoła Staroobrzędowego, nieposiadającego hierarchii duchownej). Trzeba doprecyzować, że dopuszczalność zatrudniania kapelanów nie dotyczy kościołów i innych związków wyznaniowych, które mają uregulowany status prawny w prawie obcym, lecz nie posiadają takiego przymiotu w prawie polskim $^{27}$. Nie ma natomiast żadnych ograniczeń w tym zakresie w odniesieniu do prywatnych podmiotów leczniczych. Należy zatem przyjąć, że wszystkie wspólnoty religijne mające unormowane położenie prawne będą mogły ubiegać się o zatrudnienie kapelana. Wymaga tego poszanowanie zasady równouprawnienia kościołów i innych związków wyznaniowych (art. 25 ust. 1 Konstytucji). Cechą relewantną będzie fakt uregulowania statusu prawnego grupy religijnej w prawie polskim. Nie powinno dochodzić w tym przypadku do różnicowania statusu poszczególnych denominacji religijnych $z$ uwagi na tryb określenia stosunku państwa do danej grupy, aczkolwiek mamy do czynienia z takimi przypadkami w prawie polskim $^{28}$. Za przyjęciem takiego poglądu przemawia konieczność zachowania ostrożności w wydatkowaniu środków publicznych. Występuje bowiem niebezpieczeństwo wykorzystywania przepisu art. 38 u.p.p.R.P. do pozyskania pieniędzy publicznych pod płaszczem realizacji praw pacjenta

26 Tamże, 228.

27 Tamże, 229.

28 Przykładem może być zawężenie możliwości zawierania małżeństw wyznaniowych ze skutkami cywilnymi jedynie do kościołów i innych związków wyznaniowych, wobec których dopuszcza to ratyfikowana umowa międzynarodowa lub ustawa (por. art. $1 \S 3$ ustawy z dnia 25 lutego 1964 r. - Kodeks rodzinny i opiekuńczy (tekst jedn. Dz.U. z 2017 r., poz. 682 z późn. zm.). 
z art. 36 i 37 u.p.p.R.P. przez zrzeszenia pozorujące wspólnotę religijną. Postępujący pluralizm światopoglądowy sprawia, że w otaczającej nas rzeczywistości społecznej ciągle przybywa wiele niezinstytucjonalizowanych systemów światopoglądowych, co uniemożliwia lub znacznie utrudnia uchwycenie istniejących grup religijnych. W odniesieniu do wspólnot religijnych istniejących faktycznie należałoby przyjąć, że duchowni z tych grup mogą prowadzić swoją działalności religijną wobec pacjentów w obrębie podmiotów leczniczych, natomiast nie będzie możliwe zatrudnianie duchownych oraz pozyskiwanie środków publicznych od podmiotów leczniczych z tytułu prowadzonej posługi duszpasterskiej. Należy jednak wyraźnie podkreślić, że brak określenia statusu wspólnoty religijnej na gruncie prawa polskiego nie może rzutować na położenie prawne duchownego w zakresie uprawnień, których realizacja pozostaje w zbiegu z innymi prawami pacjenta. Przykładem może być kontakt każdego duchownego z pacjentem, co może zostać równocześnie zakwalifikowane jak przejaw realizacji „prawa pacjenta do poszanowania życia prywatnego i rodzinnego" oraz „,prawa do opieki duszpasterskiej”. Należy bowiem pamiętać o tym, że każdy pacjent ma prawo do odwiedzin i odmowa dopuszczenia duchownego do pacjenta godziłaby nie tylko w jego wolność sumienia i religii (art. 53 ust. 2 zd. 2 in fine Konstytucji), ale również w prawo do ochrony życia prywatnego (art. 47 Konstytucji). Wykluczenie osób duchownych mogłoby być również przejawem przełamania zakazu dyskryminacji na tle wyznaniowym. Trzeba więc przyjąć, że każdy duchowny, bez względu na status wspólnoty religijnej, którą reprezentuje, może korzystać z możliwości odwiedzin pacjenta, oczywiście zgodnie z zasadami porządku przyjętymi w danym podmiocie leczniczym, a wszelkie ograniczenia w tym zakresie wymagają spełnienia przesłanek limitacji praw i wolności konstytucyjnych. Można wyobrazić sobie ograniczenie prawa do opieki duszpasterskiej z uwagi na stan poważnego zagrożenia epidemiologicznego ${ }^{29}$. Do takiego wniosku skłania również stwierdzenie, że wolność sumienia i religii przysługuje każdemu bez względu na status grupy religijnej, gdyż zgodnie z orzecznictwem TK, ,wolność religii ujmowana jest w normie konstytucyjnej bardzo szeroko (...) nie jest ona ograniczona do uczestnictwa we wspólnotach religijnych tworzących formalną, wyodrębnioną

29 Wałachowska 2009, 232-233. 
strukturę organizacyjną i zarejestrowaną w stosownych rejestrach prowadzonych przez władzę publiczną" ${ }^{30}$.

Jak już wyżej wspomniano, jedynie dwie wspólnoty religijne mają wprost zagwarantowaną możliwość zatrudniania kapelanów. Nie da się obecnie wskazać przepisu ustawowego, który stanowiłby kompetencję dla kierowników podmiotów leczniczych do nawiązywania stosunku pracy z duchownymi pozostałych denominacji religijnych. Wyżej przesądzono, że chodzi tu jedynie o te wspólnoty religijne, które mają uregulowany status prawny w prawie polskim. Brak unormowań w tej kwestii skłania do sformułowania postulatu de lege ferenda w sprawie dodania odpowiedniej regulacji prawnej w przepisach u.g.w.s.w. lub u.p.p.R.P. Jego treść można sformułować następująco: kapelani kościołów i innych związków wyznaniowych o uregulowanej sytuacji prawnej mogą być zatrudniani w podmiotach leczniczych wykonujących działalność leczniczą w rodzaju stacjonarne i całodobowe świadczenia zdrowotne. Nie wydaje się zasadne doprecyzowywanie w przepisach form zatrudnienia, gdyż powinno się zapewnić w tym zakresie odpowiednią swobodę podmiotom leczniczym i duchownym, aczkolwiek w granicach ram prawnych wyznaczonych przepisami prawa pracy oraz prawa cywilnego. Z punktu widzenia standardów techniki legislacyjnej, wydaje się, że nie byłoby właściwym rozwiązaniem wprowadzanie odrębnych przepisów prawnych w każdej ustawie indywidualnej o stosunku państwa do danego kościoła lub związku wyznaniowego. Po pierwsze, należy dążyć do zwięzłego regulowania zagadnień prawnych, a powtarzanie tej samej kwestii w kilkunastu aktach prawnych temu przeczy. Po drugie, mogłoby przy tym dojść nawet do zupełnie przypadkowego przeoczenia jednej ze wspólnot religijnych, co byłoby wysoce niepożądane. Przykładem chaosu legislacyjnego może być fakt, że jedynie osiem ustaw indywidualnych zobowiązuje kierowników państwowych lub samorządowych placówek do przeznaczenia odpowiednich pomieszczeń w celu organizowania zbiorowych praktyk religijnych ${ }^{31}$. I po trzecie wreszcie, taki zabieg legislacyjny nadal nie poskutkowałby objęciem zakresem przedmiotowym regulacji tych kościołów i innych związków wyznanio-

30 Zob. wyrok TK z 16 lutego 1999 r., SK 11/98, OTK z 1999 r. Nr 2, poz. 22, LEX nr 36175 .

31 Mezglewski 2008, 205. 
wych, których sytuacja prawna uregulowana została w drodze decyzji administracyjnej, a jak wiadomo jest to powszechny tryb w praktyce prawniczej $^{32}$. Przepis ten powinien znaleźć się w regulacjach u.g.w.s.w.

Żaden przepis prawa polskiego nie określa liczby stanowisk kapelana szpitalnego. Trudno wskazać liczbę zatrudnianych obecnie kapelanów w podmiotach leczniczych, gdyż tego typu dane nie są gromadzone ${ }^{33}$. Według danych szacunkowych przyjmuje się, że w Polsce zatrudnionych jest ok. 1000 duchownych w podmiotach leczniczych ${ }^{34}$. Nie istnieją dane na temat liczby i formy zatrudniania tych kapelanów, ponieważ żadna struktura państwowa nie prowadzi tego typu ewidencji. Wynika to nie tyle z dużej liczby placówek leczniczych, czy ich zróżnicowanego statusu, lecz przede wszystkim z braku wydzielonych środków finansowych na ten cel w budżecie. Opieka duszpasterska nie jest świadczeniem zdrowotnym, tak więc nie jest prowadzona sprawozdawczość w tym zakresie przez organy administracji ochrony zdrowia. Nieco inaczej przedstawia się znajomość danych o współpracy z kapelanami w podmiotach leczniczych afiliowanych przy strukturach państwowych. Dla przykładu można wskazać, że w 28 podmiotach leczniczych Ministerstwa Spraw Wewnętrznych i Administracji opiekę duszpasterską sprawowało 26 kapelanów zatrudnionych na 14,65 etatu ${ }^{35}$. Precyzyjne dane mogą również zostać przedstawione w odniesieniu do zatrudniania kapelanów w jednostkach penitencjarnych. Według danych na dzień 31 grudnia 2017 roku, w Służbie Więziennej było zatrudnionych 190 kapelanów, w tym 29 w pełnym wymiarze, a pozostali na określoną część etatu ${ }^{36}$.

Warto rozważyć, czy dana placówka może zatrudnić na stanowiskach kapelańskich duchownych reprezentujących różne wspólnoty religijne. Ilość etatów kapelańskich w podmiotach leczniczych nie jest limitowana przez przepisy prawa. Granicę wyznaczają zapewne możliwości finansowe

32 Ożóg 2015, 23.

33 Łukasz Kasper, Opieka duszpasterska w szpitalach $i$ więzieniach, http://idziemy.pl/ kosciol/opieka-duszpasterska-w-szpitalach-i-wiezieniach/3/ [dostęp: 11.07.2018].

34 Http://www.rynekzdrowia.pl/Finanse-i-zarzadzanie/Posluga-duchowa-ile-zarabia-szpitalny-kapelan,6970,1.html [dostęp: 11.07.2018].

35 Strzelecki 2012, 117.

36 Https://ekai.pl/naczelny-kapelan-wieziennictwa-potrzeba-kapelanow-bardziej-mobilnych/ [dostęp: 10.07.2018]. 
oraz skala potrzeb. Dopuszczalna wydaje się polityka kadrowa oparta na zatrudnianiu duchownych z różnych kościołów i związków wyznaniowych w niepełnym wymiarze czasu pracy lub na pełnych etatach. Nie sposób przedstawić jednolite wytyczne w tym zakresie. Podmiot leczniczy ma natomiast obowiązek zapewnić pacjentom opiekę duszpasterską i to od jego kierownictwa zależeć będzie w jaki sposób ukształtowana zostanie współpraca z duchownymi. Należy jednak dążyć do zapewnienia zbliżonych warunków pracowniczych i ubezpieczeniowych dla wszystkich kapelanów reprezentujących poszczególne wspólnoty religijne i nie doprowadzać do sytuacji zróżnicowanego traktowania, jeżeli nie przemawiają za tym usprawiedliwione powody. Należy przede wszystkim dążyć do zapewnienia efektywności systemu gwarancji prawa do opieki duszpasterskiej. Z oczywistych względów nie jest możliwe zatrudnianie duchownych wszystkich denominacji religijnych. Wydaje się, że w praktyce kluczowym czynnikiem będzie struktura wyznaniowa regionu kraju. Zasadniczo w każdej placówce możemy spotkać kapelana wiernych rzymskokatolickich, a także największych liczebnie wspólnot religijnych ${ }^{37}$. Można spodziewać się, że na terenach z wyższym odsetkiem przedstawicieli wyznań mniejszościowych wystąpi potrzeba nawiązania współpracy podmiotu leczniczego z duchownym określonej denominacji.

Trudno wskazać jakiekolwiek mierniki w zakresie liczby kapelanów w stosunku do ilości pacjentów. Warto wskazać, że partykularny prawodawca kościelny podejmuje w swoich regulacjach interesującą próbę określenia liczby kapelanów w powiązaniu z ilością łóżek szpitala. Tego typu relacja zakłada hipotetycznie, że każdy pacjent stanowi potencjalnego beneficjenta opieki duszpasterskiej oferowanej przez Kościół Katolicki, gdyż to o tej wspólnocie mowa w poniższym przykładzie. Jako egzemplifikację wskażę dokument pt. Statut kapelana szpitalnego zakładu opiekuńczo-leczniczego i domów opieki w Diecezji Warszawsko-Praskiej wydany przez arcybiskupa Henryka Hosera w dniu 23 września 2009 r., który przewiduje, że: „1. Placówki Służby Zdrowia do 250 łóżek zatrudniają kapelana na $1 / 2$ etatu. 2. Placówki lecznicze posiadających od 250 do 500 łóżek

37 Zob. np.: https://www.su.krakow.pl/opieka-duszpasterska, http://szpital-bochnia.pl/ informacje-dla-pacjenta/opieka-duszpaszterska/, http://uck.pl/dla-pacjentow/opieka-duszpasterska.html, http://udsk.pl/strefa-pacjenta/opieka-duszpasterska/ [dostęp: 11.07.2018]. 
zatrudniają kapelana na pełny etat. 3. Placówki Służby Zdrowia powyżej 500 łóżek winny zatrudnić dwóch i więcej kapelanów"38. Wydaje się, że powiązanie liczby łóżek z liczbą kapelanów jest uzasadnione. Im większa ilość pacjentów, tym prawdopodobnie większa będzie liczba beneficjentów prawa do opieki duszpasterskiej. Żaden prawodawca świecki ani kościelny nie jest jednak w stanie uregulować tej kwestii w precyzyjny sposób, gdyż może się okazać, że niewielka liczba pacjentów będzie przejawiać wysoki poziom potrzeb religijnych, a z kolei równie prawdopodobna może być sytuacja, gdy w dużym szpitalu poziom religijności pacjentów jest bardzo niski, co powoduje niewielkie zapotrzebowanie na posługę duchownego. $\mathrm{Z}$ pewnością powyższa regulacja może stanowić punkt odniesienia dla kierowników placówek medycznych, aczkolwiek nie jest ona wiążąca z uwagi na zasadę autonomii państwowego i kościelnego porządku prawnego (art. 25 ust. 3 Konstytucji, art. 1 Konkordatu). Kierownictwo podmiotów leczniczych może przyjmować własne wytyczne w tym zakresie i mogą one odbiegać od regulacji prawa kościelnego.

\section{FORMA ZATRUDNIENIA}

Przepisy aktów prawnych dopuszczających wprost zatrudnianie kapelanów nie określają $\mathrm{w}$ ogóle formy nawiązania stosunku pracy z duchownym, co stanowi konsekwencję braku przepisów prawnych dotyczących zatrudniania kapelanów (z wyjątkiem regulacji prawnych dotyczących wspomnianych dwóch wspólnot religijnych). Art. 17 ust. 3 Konkordatu jedynie przewiduje, że „,(..) biskup diecezjalny skieruje kapelanów, z którymi odpowiednia instytucja zawrze stosowną umowę (...)". Na podstawie treści Konkordatu nie sposób przesądzić, czy przepis ten dotyczy umowy w znaczeniu potocznym, jako porozumienia zawieranego przez podmiot leczniczy ze wspólnotą religijną w kwestiach organizacyjnych duszpasterstwa, czy też ma być to umowa, której treścią jest nawiązanie stosunku zatrudnienia z wykorzystaniem dopuszczalnych form przewidzianych w prawie pracy lub prawie cywilnym. Forma prawna współpracy duchownego

38 Http://diecezja.waw.pl/medicina/aktualnosci/Statut_Kapelana_Szpitalnego.htm. [dostęp: 1.12.2017]. 
z podmiotem leczniczym stanowi niezwykle istotną kwestię i zasługuje na odpowiednie unormowanie. Niestety żadnych wskazówek nie dostarcza również przepis art. 31 ust. 2 ustawy z dnia 17 maja 1989 r. o stosunku Państwa do Kościoła Katolickiego w Rzeczypospolitej Polskiej, w którym jedynie przyjęto, że „,...) kierownicy właściwych zakładów państwowych zatrudniają kapelanów skierowanych przez biskupa diecezjalnego". Przepis ten nie określa formy zatrudnienia. W doktrynie prawa wyznaniowego wyrażono stanowisko, że ma być to umowa o pracę dotycząca świadczenia posługi duszpasterskiej w danej placówce ${ }^{39}$. Trzeba jednak stwierdzić, że przepis prawny wprost tego nie przesądza i powyższe stwierdzenie nie znajduje wyraźnego oparcia normatywnego. Analogiczne przyjęto także w art. 27 ust. 2 ustawy z dnia 4 lipca 1991 r. o stosunku Państwa do Polskiego Autokefalicznego Kościoła Prawosławnego, zgodnie z którym „(...) kierownicy właściwych zakładów państwowych zatrudnią kapelanów, jeżeli zostaną oni skierowani przez biskupa diecezjalnego (...)”.

Porównawczo można wspomnieć, że zgodnie z wolą prawodawcy organizacja duszpasterstwa $\mathrm{w}$ jednostkach penitencjarnych ma być oparta na umowie, której treść powinna dotyczyć zasad współpracy strony kościelnej z dyrekcją zakładów karnych i aresztów śledczych. Jest to zatem umowa w znaczeniu porozumienia o współpracy bez uwzględnienia formy zatrudnienia. Mianowicie, rozporządzenie Ministra Sprawiedliwości z dnia 2 września 2003 r. w sprawie szczegółowych zasad wykonywania praktyk religijnych i korzystania z posług religijnych w zakładach karnych i aresztach śledczych ${ }^{40}$ przewiduje, że ,w celu zapewnienia skazanym wykonywania praktyk religijnych i korzystania z posług religijnych dyrektor zakładu zawiera umowę z kapelanem o wykonywanie posług religijnych". Umowa o wykonywanie posług religijnych stanowi umowę nienazwaną, która jest w pełni dopuszczalna na podstawie zasady swobody umów. Treść $\$ 3$ pkt 1 rozporządzenia precyzuje, że „W umowie określa się w szczególności zakres czynności kapelana, zasady jego zastępstwa przez innego duchownego, zakres i zasady korzystania przez kapelana przy wykonywaniu posług religijnych z pomocy innych osób, zasady współdziałania z dyrektorem zakładu oraz przypadki, w których umowa ulega rozwiązaniu”. Nie ulega wątpliwo-

39 Krukowski 2008, 188.

40 Dz.U. z 2003 r. Nr 59, poz. 1549. 
ści, że szczególne warunki funkcjonowania jednostek penitencjarnych oraz wymogi bezpieczeństwa wymagają precyzyjnego określenia zasad przebywania kapelana i osób trzecich w tych placówkach. Wydaje się, że nie ma żadnych przeszkód, aby również w podmiotach leczniczych zawierane były tego typu umowy ramowe o pełnienie posługi duszpasterskiej. W żadnym wypadku nie może przy tym jednak dochodzić do kształtowania treści i kierunku działalności duszpasterskiej. Zawarcie umowy o świadczenie posługi duszpasterskiej w podmiocie leczniczym znajduje szczególne uzasadnienie w przypadkach, gdy osoba duchowna pełni swoją posługę w podmiocie leczniczym bez zatrudnienia, tak więc wówczas można określić jej status za pomocą umowy o świadczenie wolontariatu. Zawarcie umowy w znaczeniu porozumienia będzie zawsze lepszym rozwiązaniem od braku jakiegokolwiek określenia zasad współpracy. Fakt ponoszenia odpowiedzialności prawnej przez podmioty lecznicze za brak zagwarantowania prawa do opieki duszpasterskiej powinien skłaniać kierownictwo tych placówek do określenia ram prawnych współpracy z kapelanem.

Prawodawca kościelny w regulacjach wewnętrznych Kościoła Katolickiego wprost przyjął jednak, że w odniesieniu do zatrudnienia duchownych w podmiotach leczniczych ma być zawarta umowa o pracę ${ }^{41}$. W dokumencie „Status kapelana Archidiecezji Katowickiej” przyjęto że „duszpasterstwo w szpitalu sprawuje kapelan szpitalny, tj. kapłan delegowany przez Arcybiskupa katowickiego i zatrudniony na podstawie umowy o pracę w określonym wymiarze godzin na stanowisku kapelana"42. Ze wspomnianych względów konstytucyjnych (art. 25 ust. 3 Konstytucji) również i w tej kwestii powyższa regulacja nie ma waloru powszechnego obowiązywania. Przepisy te nie kreują roszczenia duchownego wobec kierownika podmiotu leczniczego o zawarcie umowy o pracę dla osoby na stanowisku kapelana w danej placówce. Zwykle zatrudnia się kapelanów w publicznych podmiotach leczniczych na określoną część etatu ${ }^{43}$.

${ }^{41}$ Http://www.archidiecezja.katowice.pl/dokumenty/8079-status-kapelana-szpitalnego-w-archidiecezji-katowickiej oraz http://dsz.bielsko.pl/assets/Status-Kapelana.pdf [dostęp: 5.12.2017]. Regulacja dotycząca Diecezji Bielsko-Żywieckiej przewiduje wykonywanie posługi duszpasterskiej także w formie wolontariatu.

42 Tamże, dot. Archidiecezji Katowickiej.

43 Łukasz Kasper, Opieka duszpasterska w szpitalach $i$ więzieniach, http://idziemy.pl/ kosciol/opieka-duszpasterska-w-szpitalach-i-wiezieniach/3/ [dostęp: 11.07.2018]. 
Umowa o pracę może stanowić jedną z form zatrudnienia kapelana szpitalnego. Jest to najdalej idące powiązanie duchownego $\mathrm{z}$ podmiotem leczniczym, biorąc pod uwagę skutki prawne dla obu stron. W tym sensie można uznać, że wykonywanie posługi duszpasterskiej na podstawie umowy o pracę efektywnie zabezpiecza realizację prawa do opieki duszpasterskiej, ponieważ stosunek prawny wynikający z umowy o pracę precyzyjnie określa prawa i obowiązki duchownego oraz podmiotu leczniczego. Przepis art. 22 §1 ustawy z dnia 26 czerwca 1974 r. - Kodeks pracy ${ }^{44}$ stanowi, że ,przez nawiązanie stosunku pracy pracownik zobowiązuje się do wykonywania pracy określonego rodzaju na rzecz pracodawcy i pod jego kierownictwem oraz w miejscu i czasie wyznaczonym przez pracodawcę, a pracodawca - do zatrudniania pracownika za wynagrodzeniem”. Treść umowy z duchownym może zawierać wskazanie zakresu obowiązków duchownego, poprzez ich rodzajowe wyliczenie, np. odprawianie mszy świętych $\mathrm{z}$ określoną częstotliwością w ciągu tygodnia, odbywanie rozmów z pacjentami, sprawowanie sakramentów, itp. „Rodzaj pracy” w rozumieniu przepisu art. $22 \S 1$ k.p. jest szczególny w rozważanym przypadku, gdyż dotyczy sprawowania posługi duszpasterskiej wobec pacjentów w zakresie określonym w umowie. Treść umowy o świadczenie pracy duchownego w podmiocie leczniczym nie może jednak zawierać postanowień, które ingerowałyby w kierunek pracy kapelana, ponieważ w tej sferze wyłączną kompetencję posiada duchowny, a także wspólnota religijna, którą on reprezentuje. W dużym stopniu swoboda działań duchownego jest zdeterminowana nauczaniem wspólnoty religijnej. Powyższy wniosek znajduje uzasadnienie również $\mathrm{w}$ konieczności poszanowania zasady bezstronności światopoglądowej władz publicznych z art. 25 ust. 2 Konstytucji. Trudno bowiem wyobrazić sobie ingerencję pracowników podmiotu leczniczego w pracę duszpasterską. „Kierownictwo” pracodawcy należy zatem rozumieć w specyficzny sposób, polegający w tym wypadku jedynie na wydawaniu poleceń w związku z koniecznością wykazania dyspozycyjności duchownego w celu realizacji opieki duszpasterskiej, co może oznaczać np. obowiązek stawiennictwa kapelana w podmiocie leczniczym w razie pogorszenia się stanu zdrowia lub zagrożenia życia pacjenta, aby uczynić zadość uprawnieniu z art. 37 u.p.p.R.P., uczestnictwo zebraniach pracow-

44 Tekst jedn. Dz.U. z 2018 r., poz. 917, dalej: k.p. 
ników placówki medycznej, obecność na obligatoryjnych szkoleniach pracowniczych, odbywanie kursu z zakresu bezpieczeństwa i hieny pracy, itd. Natomiast w żadnym wypadku „kierownictwo” nie obejmuje uprawnienia do wydawania poleceń służbowych w zakresie kształtowania treści i form działań duszpasterskich kapelana.

Miejsce świadczenia pracy nie jest zdefiniowane w przepisach k.p. Natomiast art. $128 \S 1$ k.p. określa, że „czasem pracy jest czas, w którym pracownik pozostaje $\mathrm{w}$ dyspozycji pracodawcy $\mathrm{w}$ zakładzie pracy lub w innym miejscu wyznaczonym do wykonywania pracy". Mając powyższe na uwadze można przyjąć, że miejscem pracy kapelana będzie budynek podmiotu leczniczego, w tym przede wszystkim sale chorych, w których przebywają pacjenci. Szczególnym miejscem pracy kapelana szpitalnego jest kaplica szpitalna lub inne odpowiednie pomieszczenie, w którym odprawiane są przez duchownego zbiorowe praktyki religijne.

Problematyczne pozostaje określenie czasu pracy kapelana w podmiocie leczniczym, co wynika ze specyfiki prowadzonej posługi duszpasterskiej. Część obowiązków kapelana można w jakimś stopniu określić czasowo w umowie ze wskazaniem liczby godzin, jeśli idzie o wykonywanie regularnych posług, takich jak np.: odprawianie mszy świętej z ustaloną częstotliwością, udzielanie sakramentów pacjentom (pokuta, namaszczenie chorych) w ustalonym przedziale godzin. Natomiast w pewnych przypadkach czas pracy kapelana w bezpośrednim kontakcie z pacjentami może być jednak trudny do ujęcia w sztywnych ramach czasowych z uwagi na indywidualne potrzeby poszczególnych pacjentów i zdarzenia losowe. Mianowicie kondycja duchowa poszczególnych beneficjentów prawa do opieki duszpasterskiej może wymagać od kapelana większej uwagi i zainteresowania, co przyczyni się do wydłużenia czasu pracy. Z kolei posługa duszpasterska w zakresie udzielania sakramentu namaszczenia chorych powinna być dostępna całodobowo przez siedem dni w tygodniu w odniesieniu do osób w znajdujących się w stanie zagrożenia życia lub pogorszenia stanu zdrowia, co sprawia, że nie sposób ustalić z góry w umowie czasu koniecznego do realizacji prawa do kontaktu z duchownym (art. 37 u.p.p.R.P.), ponieważ jest to niemożliwe z oczywistych powodów. Z powyższych względów w pełni zasadne wydaje się zastosowanie zadaniowego trybu pracy do ustalenia czasu pracy kapelana w podmiocie leczniczym. Należy uprzednio podjąć porozumienie, w którym dokona się ustalenia 
obowiązków duchownego w taki sposób, aby przy dołożeniu „należytej staranności i sumienności”(art. 101 §1 k.p.) możliwe było ich wykonanie w ciągu 8 godzin na dobę i średnio w 5 dniowym tygodniu pracy w ustalonym okresie rozliczeniowym (art. 129 k.p.) ${ }^{45}$. Kierownictwo podmiotu leczniczego nie może jednak wprowadzić zadaniowego trybu pracy bez konsultacji z kapelanem. Sąd Najwyższy w wyroku z 15 marca 2006 r. uznał bowiem, że ,porozumienie” z art. 140 k.p. z pracownikiem nie stanowi uzgodnienia, lecz ma charakter konsultacji. Stwierdzono również, że brak takiego porozumienia nie skutkuje nieskutecznością ustanowienia zadaniowego systemu czasu pracy, lecz w sytuacji zaistnienia sporu powoduje po stronie pracodawcy konieczność wykazania, że powierzone pracownikowi zadania zostały prawidłowo wyznaczone ${ }^{46}$. System zadaniowy zakłada daleko idącą samodzielność pracownika w wykonywaniu pracy, a pracodawca określa przy tym zakres zadań, które mają być wykonane, czas do realizacji, a sposób wypełnienia obowiązków zostaje powierzony pracownikowi ${ }^{47}$. W praktyce można spotkać szczegółowy plan tygodniowy pracy duchownego, który zakłada obsługę pacjentów z poszczególnych pięter (kondygnacji) szpitala w dane dni tygodnia ${ }^{48}$. Przytoczony powyżej przykład wskazuje na wtorek, jako „dzień wolny”, wyłączony z posługiwania wobec pacjentów. Mając na uwadze prawo do urlopu kapelana, jak każdego pracownika, to wydaje się jednak, że posługa duchownego powinna być dostępna dla pacjentów w każdym dniu tygodnia, tak więc należy przewidzieć zastępstwo lub tryb zmianowy pracy duchownych, tak aby pacjenci nie mieli poczucia zagrożenia braku dostępności duchownego w podmiocie leczniczym. Wyraźnie dostrzega tę konieczność prawodawca kościelny we wskazanych przykładach regulacji dot. Kościoła katolickiego i nakłada obowiązek wyznaczenia osoby zastępującej kapelana na czas trwania urlopu danego duchownego.

Zatrudnienie nie musi mieć formy pracowniczej, gdyż w pełni dopuszczalne jest wykorzystanie umów prawa cywilnego ${ }^{49}$. Jedną z takich

\footnotetext{
45 Jaśkowski 2018.

46 Wyrok SN z 15 marca 2006 r., II PK 165/2005, LEX nr 232583.

47 Stefański 2016.

48 Http://www.szpitalwolomin.pl/opieka-duszpasterska.html [dostęp: 10.07.2018].

49 Zob. wyrok SN z dnia 9 grudnia 1999 r., sygn. I PKN 432/99, LEX nr 39601.
} 
form może być świadczenie pracy na podstawie umowy zlecenia. Warto nadmienić, że była to forma wprost przewidywana przez prawodawstwo PRL - w pewnym okresie czasu - w odniesieniu do zatrudniania kapelanów w podmiotach leczniczych. Mianowicie w dniu 16 grudnia $1950 \mathrm{r}$. wydane zostało zarządzenie Ministra Zdrowia w sprawie wysokości wynagrodzeń kapelanów szpitalnych, w którym przyjęto: „1. Dyrekcja zakładów leczniczych obowiązane są zawrzeć umowę zlecenia $\mathrm{z}$ duchownymi, którzy zostali umówieni jako kapelani szpitalni”. Przedmiotowe zarządzenie określało także elementy treściowe tej umowy, przyjmując, że „,[u] mowa zlecenia powinna określać wysokość ryczałtowego wynagrodzenia oraz stwierdzać, że zleceniodawcy nie przysługują z tytułu tej umowy świadczenia socjalne, ulgi kolejowe, ani mieszkanie. 3. Wynagrodzenie należy ustalić w granicach od 150 do 300 zł. w zależności od charakteru zakładu. 4. W każdym przypadku dyrekcja zakładu obowiązana jest uprzednio uzgodnić wysokość wynagrodzenia z kierownikiem wydziału zdrowia oraz kierownikiem referatu wyznań prezydium wojewódzkiej rady narodowej. 5. Duchowny może być równocześnie kapelanem w kilku zakładach leczniczych, w tym przypadku dyrekcja każdego zakładu powinna z nim zawrzeć osobną umowę"50. Konferencja Episkopatu Polski postulowała jednak zawieranie umów o pracę, zamiast umowy zlecenia, ponieważ dążono do tego, aby zagwarantować kapelanom ubezpieczenie ZUS z uwagi na niebezpieczeństwo dla zdrowia w związku z wypełnianiem posług duszpasterskich ${ }^{51}$. Postulaty Kościoła Katolickiego zostały uwzględnione w Instrukcji Ministra Zdrowia i Opieki Społecznej z dnia 9 września 1981 roku w sprawie zapewnienia posług religijnych chorym przebywającym w szpitalach, sanatoriach i domach pomocy społecznej ${ }^{52}$. W myśl tego aktu kapelan był kierowany do pracy przez władzę kościelną, zawierana miała być umowa o pracę w charakterze kapelana $\mathrm{z}$ wynagrodzeniem określonym przez odrębne przepisy (§6).

Dzisiejszy stan prawny nie przewiduje elementów treściowych umowy zlecenia dla pełnienia posługi duszpasterskiej w podmiocie leczniczym. Należy zatem uwzględnić ogólne przepisy prawa cywilnego z uwzględ-

\footnotetext{
50 Fąka 1978, 126.

51 Ratajczak 2002, 117.

52 Tamże, 118.
} 
nieniem specyfiki przedmiotu świadczenia. Przedmiotem umowy zlecenia nie może być świadczenie określonych posług duszpasterskich, np. mszy świętej, udzielania sakramentu namaszczenia chorych, sprawowanie sakramentu pokuty, itd. Zgodnie bowiem z art. $734 \S 1$ ustawy z dnia 23 kwietnia 1964 r. - Kodeks cywilny ${ }^{53}$ przez umowę zlecenia przyjmujący zlecenie zobowiązuje się do dokonania określonej czynności prawnej dla dającego zlecenie. Należy podkreślić, że wymienione powyżej formy posługi duszpasterskiej nie mogą stanowić czynności prawnych w rozumieniu prawa państwowego i nie stanowią przedmiotu umowy zlecenia ${ }^{54}$. Czynność prawna jest to „skonstruowana przez system prawny czynność konwencjonalna podmiotu prawa cywilnego, której treść określa - co najmniej w podstawowym zakresie - konsekwencje prawne tego zdarzenia prawnego (art. 56 k.c.)" 55 . W związku z tym przedmiotem umowy zlecenia może być jedynie wykonywanie działalności duszpasterskiej, której zakres może zostać określony w ogólny sposób ${ }^{56}$. Umowa zlecenia nie zapewnia kapelanowi takich praw, które ma osoba zatrudniona w oparciu o umowę o pracę, gdyż zatrudnienie na podstawie umowy prawa cywilnego jedynie w ograniczonym obszarze związane jest ze stosowaniem regulacji prawa pracy $^{57}$. Umowa zlecenia nie kształtuje stosunku prawnego z podmiotem leczniczym w taki zakresie, jaki wynika z umowy o pracę, ponieważ stawia w mniej korzystnej sytuacji prawnej duchownego. Oczywiście wybór takiej formy ukształtowania stosunku prawnego z duchownym nie przekreśla automatycznie możliwości zapewnienia pacjentom prawa do opieki duszpasterskiej.

Można również odnotować przypadki sprawowania posługi duszpasterskiej bez jakiejkolwiek umowy ${ }^{58}$. W takim przypadku duchowny może być uznany za wolontariusza. Jego relacja z podmiotem leczniczym jest najsłabsza i ogranicza się w zasadzie do przestrzegania norm

53 Tekst jedn. Dz.U. z 2018 r., poz. 1025, dalej: k.c.

54 Jarosław Masłowski, Czy odprawianie mszy może być przedmiotem umowy zlecenia?, https://www.kadry.abc.com.pl/narzedzia-i-materialy/pytania-i-odpowiedzi/czy-odprawianie-mszy-moze-byc-przedmiotem-umowy-zlecenia,73792.html [dostęp: 11.07.2018].

55 Radwański, Olejniczak 2011, 218.

56 Masłowski, Czy odprawianie mszy może być przedmiotem umowy zlecenia?

57 Florczak 2015, 241 i n.

58 Stanisz 2016, 325. 
przyjętych w danej placówce i dopuszczeniu duchownego do pacjen$t^{59}$. Warto wskazać na szczególną sytuację, gdy zawierana jest umowa o świadczenie posługi duszpasterskiej nie z duchownym, a z jednostkami organizacyjnymi wspólnot religijnych (jak to występuje na przykład na Malcie $)^{60}$. Zgodnie z art. 2 pkt 3 ustawy z dnia z dnia 24 kwietnia 2003 r. o działalności pożytku publicznego i o wolontariacie, przez wolontariusza należy rozumieć „osobę fizyczną, która ochotniczo i bez wynagrodzenia wykonuje świadczenia na zasadach określonych w ustawie"61. Art. 42 ust. 1 pkt 4 u.d.p.p.w. przewiduje wprost możliwość wykonywania świadczeń na rzecz podmiotów leczniczych w rozumieniu przepisów o działalności leczniczej w zakresie wykonywanej przez nie działalności leczniczej. Kierownik podmiotu leczniczego powinien zawrzeć odpowiednie porozumienie z duchownym - wolontariuszem, którego treść określałaby zasady świadczenia opieki duszpasterskiej, a w zakresie nieuregulowanym zastosowanie znalazłyby przepisy k.c. Przepisy u.d.p.p.w. wraz z porozumieniem mogą wyznaczać ramy prawne dla współpracy duchownego z podmiotem leczniczym. W literaturze wskazano również dopuszczalność pełnienia wolontariatu na podstawie umowy zlecenia, ponieważ element wynagrodzenia nie jest dla niej konieczny dla tej formy zatrudnienia ${ }^{62}$. Umowa o wykonywanie wolontariatu nie gwarantuje dostępności kapelana w takim wymiarze, jak umowy nawiązujące stosunek zatrudnienia, ponieważ kierownictwo podmiotu leczniczego nie dysponuje rozwiązaniami prawnym umożliwiającymi podejmowanie działań kierowniczych względem duchownego, jeśli idzie o jego obecność w placówce na wezwanie pracownika podmiotu leczniczego. Z punktu widzenia odpowiedzialności prawnej podmiotu leczniczego za brak dostępności prawa do opieki duszpasterskiej jest to najmniej korzystna forma nawiązania współpracy.

\footnotetext{
59 Tamże, 324.

60 Tamże, 325.

61 Dz.U. z 2018 r., poz. 450.

62 Musiała 2003, 25-26.
} 


\section{WYBÓR OSOBY NA STANOWISKO KAPELANA I SKIEROWANIE DO POSŁUGI}

Kapelan pełni posługę w podmiocie leczniczym i w przedstawionym powyżej zakresie podlega kierownictwu placówki medycznej, jeśli idzie o realizację umowy o pełnienie posługi duszpasterskiej. Nie oznacza to jednak, że podmiot leczniczy ma wpływ na obsadę stanowisk kapelańskich. Wykładnia językowa wyrażenia „kapelan” jednoznacznie sugeruje, że jest to osoba duchowna, należąca do stanu duchownego i upoważniona przez właściwe władze kościoła lub innego związku wyznaniowego do pełnienia określonych funkcji religijnych. Nie ulega bowiem wątpliwości, że to właśnie system prawa wewnętrznego wspólnot religijnych określa wymogi konieczne do spełnienia przez kandydatów do pracy w duszpasterstwie w podmiotach leczniczych. Jest to związane z tym, że osoba na stanowisku kapelana reprezentuje określony kościół lub inny związek wyznaniowy, ponieważ zostaje skierowana do pracy w podmiocie leczniczym przez właściwego przedstawiciela władzy wspólnoty religijnej. Interesującą kwestią do rozważenia pozostaje ustalenie dopuszczalności zatrudnienia osoby świeckiej w charakterze kapelana. Zasadniczo w realiach polskich nie występuje problem z dostępnością kapłanów wśród chorych, jednakże można wyobrazić sobie ideę aktywizacji osób świeckich w roztaczaniu troski nad chorymi i wystąpienie ewentualnego pytania o możliwość sformalizowania współpracy takich osób z podmiotami leczniczymi. Teoretycznie można sobie również wyobrazić istnienie wspólnoty religijnej bez wyodrębnionego stanu duchownego. Prawo polskie w żaden sposób nie określa wymogów do objęcia stanowiska kapelana, co wydaje się zrozumiałe, biorąc pod uwagę zasadę niezależności kościołów i innych związków wyznaniowych we własnym zakresie działania, a duszpasterstwo specjalne w podmiotach leczniczych należy bez wątpienia do tej sfery. Wydaje się, że w przedmiotowym rozporządzeniu termin ,kapelan szpitalny” użyte zostało jedynie na oznaczenie stanowiska, którego zajmowanie związane jest ze świadczeniem opieki duszpasterskiej i możliwością przyznania wynagrodzenia w wysokości określonej w przedmiotowych przepisach prawa. Należałoby zatem przyjąć, że prawo państwowe nie może jednostronnie ustanawiać wymogu przynależności do stanu duchownego wobec kandydatów na stanowisko kapelana, ponieważ byłoby to naruszenie wspomnia- 
nej zasady niezależności kościołów i innych związków wyznaniowych (art. 25 ust. 3 Konstytucji). Dotyczy to również regulacji wewnętrznych w podmiotach leczniczych. Wydaje się, że termin „kapelan” powinien być odniesiony do jego rozumienia przyjętego na gruncie prawa kościelnego. Dla przykładu można wskazać, że zgodnie z kan. 564 Kodeksu Prawa Kanonicznego, „kapelanem jest kapłan, któremu powierza się przynajmniej częściowo stałą troską pasterską o jakąś wspólnotę lub specjalny zespół wiernych, wykonywaną zgodnie $\mathrm{z}$ postanowieniami prawa powszechnego lub partykularnego". W praktyce oznacza to, że kapelanem katolickim będzie zwykle prezbiter, co wynika wprost z przepisów powszechnego prawa kanonicznego. Z punktu widzenia prawa państwowego nie ma natomiast przeszkód, aby inne osoby niż kapłan zajmowały stanowisko kapelana, jeżeli tylko dana osoba otrzyma odpowiednie umocowanie do pełnienia posługi duchownego, o którym mowa w przepisach ustaw o stosunku państwa do poszczególnych wspólnot religijnych. Takie podejście znajduje uzasadnienie praktyczne również w tym, że z działalności „kapelana szpitalnego” korzystają członkowie określonych wspólnot religijnych. Pomijanie treści prawa wewnętrznego kościoła lub związku wyznaniowego w obsadzie personalnej stanowisk kapelańskich mogłoby prowadzić do zatrudniania w podmiotach leczniczych osób, które nie mogą pełnić swojej posługi i ich działalność pozostawałaby bez umocowania prawno-teologicznego. Opieka duszpasterska ma swoje cele religijne i nie należy ich pomijać.

W świetle polskich uregulowań kapelan podejmuje pracę po uprzednim skierowaniu przez zwierzchnią władzę kościelną. Charakter prawny tego skierowania nie jest jasny. Jeśli przyjąć, że jest ono niezbędnym elementem do podjęcia posługi w podmiocie leczniczym, to jego utrata powinna skutkować rozwiązaniem więzi prawnej łączącej kapelana z placówką medyczną. Przyjęcie takiego skutku cofnięcia skierowania nie jest jednak powszechne w innych państwach ${ }^{63}$. Z pewnością nie bez znaczenia pozostaje w tym przypadku model relacji instytucjonalnych między państwem a kościołami i innymi związkami wyznaniowymi. Wydaje się jednak, że zasada autonomii i niezależności (art. 25 ust. 3 Konstytucji) powinna przeważyć na rzecz wiążącego waloru cofnięcia skierowania duchownego do pełnienia posługi kapelana. Oznacza to, że cofnięcie skierowania przez władzę

63 Zob. Stanisz 2016, 323. 
kościelną nie podlega możliwości zakwestionowania przez kierownictwo podmiotu leczniczego. Ocena pracy kapelana dokonywana przez kierownictwo podmiotu leczniczego pozostaje przy tym bez znaczenia. Ewentualne życzenia pacjentów również nie wpływają na decyzje kadrowe władzy kościelnej. Można porównać skutki prawne cofnięcia skierowania z cofnięciem misji kanonicznej wymaganej do nauczania religii w szkole, oczywiście z uwzględnieniem specyfiki tej instytucji. Należy przede wszystkim kierować się tym, że prowadzenie duszpasterstwa specjalnego w podmiotach leczniczych stanowi działanie własne kościołów i innych związków wyznaniowych, tak więc to odpowiednie organy wspólnot religijnych powinny mieć decydujące stanowisko w sprawie wyboru osób pełniących funkcję kapelana w podmiocie leczniczym.

\section{WYNAGRODZENIE KAPELANA I OKREŚLENIE JEGO PRZEZNACZENIA}

Kapelan zatrudniony w podmiocie leczniczym ma prawo do wynagrodzenia, którego wysokość określa rozporządzenie. Akt ten zaszeregował kapelanów do kategorii stanowisk ,pracownicy wykonujący zawód medyczny oraz inni pracownicy, których praca pozostaje w związku z udzielaniem świadczeń zdrowotnych”, z przyporządkowaniem do XV kategorii zaszeregowania według miesięcznych stawek wynagrodzenia zasadniczego wynoszącego 1590-3290 zł. W grupie XV obok kapelanów wymieniono następujące kategorie pracowników: kierownik komórki organizacyjnej: opiekuńczo-leczniczej, leczniczo-wychowawczej; kierownik sekcji statystyki medycznej i dokumentacji chorych; zastępczyni przełożonej pielęgniarek; pielęgniarka oddziałowa; pielęgniarka koordynująca i nadzorująca pracę innych pielęgniarek; zastępczyni pielęgniarki oddziałowej; specjalista pielęgniarka; specjalista położna; edukator do spraw diabetologii; edukator do spraw laktacji; specjalista technik dentystyczny; specjalista technik radioterapii; farmaceuta; perfuzjonista. Podmiot leczniczy ustalając wynagrodzenie kapelana powinien kierować się przedziałem kwotowym określonym w powyższym akcie prawnym. Konieczne jest przy tym uwzględnienie przepisu art. 13 k.p., zgodnie z którym pracownik ma prawo do godziwego wynagrodzenia za pracę. Sąd Najwyższy w wyro- 
ku z dnia 25 sierpnia 2010 r. przyjął, że ,godziwe wynagrodzenie za pracę to wynagrodzenie odpowiednie, właściwe, słuszne, rzetelne, uczciwe" ${ }^{64}$. Przede wszystkim trzeba uwzględnić rodzaj pracy i kwalifikacje pracownika, a także zakres obowiązków oraz czas pracy i jej jakość ${ }^{65}$. Kapelan, który jest pracownikiem ma również prawo do nagród, premii na ogólnych zasadach dotyczących pracowników podmiotu leczniczego. Wynagrodzenie kapelana może stanowić przedmiot wniosku osób zainteresowanych udzieleniem informacji o jego wysokości. W sprawie sądowoadministracyjnej dotyczącej bezczynności dyrektora podmiotu leczniczego w kwestii udzielenia odpowiedzi na pytanie o wynagrodzenie kapelana ${ }^{66}$, sąd nie rozstrzygnął co prawda charakteru prawnego tego typu informacji, jednakże zobowiązał organ do zajęcia stanowiska w sprawie złożonego wniosku.

Przepisy prawa polskiego nie mogą określać przeznaczenia wynagrodzenia kapelana ani też zrzec się bądź przenieść na rzecz innego podmiotu. Taki wniosek wynika z treści art. 84 k.p, zgodnie z którą ,pracownik nie może zrzec się prawa do wynagrodzenia ani przenieść tego prawa na inną osobę". Przepis ten ma na celu zabezpieczenie otrzymania przez pracownika wynagrodzenia za pracę ${ }^{67}$. Naruszenie tej normy prawnej skutkuje sankcją nieważności czynności prawnej na podstawie art. 58 k.c. w zW. z art. 300 k.p. ${ }^{68}$ Dla przykładu można wskazać, że kapelan nie może być zobowiązany przez przepisy prawa państwowego do przeznaczenia określonej części swojego wynagrodzenia na utrzymanie kaplicy szpitalnej. Możemy natomiast spotkać przypadki, gdy przepisy wewnętrzne Kościoła Katolickiego odnoszą się wprost do przeznaczenia wynagrodzenia kapelana szpitalnego. Przykładem takiej regulacji może być treść wspomnianego dokumentu Archidiecezji Katowickiej, w którym przewidziano że „6. Kapelan szpitalny niepełniący jednocześnie urzędu proboszcza lub wikariusza rezyduje w parafii wyznaczonej przez Arcybiskupa Metropolitę Katowickiego na prawach wikariusza, to znaczy proboszcz partycypuje w jego utrzymaniu, zaś kapelan wpłaca do kasy parafialnej ustaloną

64 Wyrok SN z dnia 25 sierpnia 2010 r., sygn. akt II PK 50/10, LEX nr 707421.

65 Zob. Wagner 2017.

${ }_{66}$ Wyrok Wojewódzkiego Sądu Administracyjnego w Gorzowie Wielkopolskim z dnia 7 listopada 2011 r. (sygn. akt II SAB/Go 42/12).

67 Zob. Skąpski 2016.

68 Zob. Maniewska 2016. 
W archidiecezji kwotę, przeznaczoną na utrzymanie miesięczne" ${ }^{69}$. Wydaje się, że powyższe uregulowania mogą zostać uznane za dopuszczalne na zasadzie autonomii kościelnego porządku prawnego. Jak wspomniano powyżej, zasadniczo nie jest dopuszczalne ustalanie sposobu przeznaczenia wynagrodzenia przez przełożonego, jednakże w wielu sytuacjach prawo kościelne nakłada różnego rodzaju obowiązki na duchownych, które wynikają ze specyfiki działalności wspólnoty religijnej i nie znajdują one podstaw prawnych w prawie świeckim. Dla akceptacji takich uregulowań można najogólniej przyjąć, że osoba duchowna dobrowolnie przyjmuje święcenia kapłańskie lub zakonne i zobowiązuje się również tym samym do zachowania posłuszeństwa wobec przełożonych, a także respektowania obowiązków wynikających z prawa kościelnego. Można zatem zasadniczo domniemywać dopuszczalność tego typu uregulowań.

\section{WNIOSKI KOŃCOWE}

Stosunek prawny łączący kapelana z podmiotem leczniczym może być zróżnicowany w zakresie obowiązków podmiotu leczniczego (pracodawcy) oraz praw kapelana (pracownika). Wszelkie różnice dotyczące pracowniczych oraz cywilnoprawnych form zatrudnienia znajdują swoje odzwierciedlenie także na gruncie omawianej problematyki. Prawo polskie przewiduje szereg możliwości prawnych nawiązania współpracy z duchownym. Do podstawowych form należy zaliczyć: zatrudnienie pracownicze, cywilnoprawne, a także pełnienie posługi duszpasterskiej w ramach umowy o świadczenie wolontariatu. Faktyczna jakość współpracy duchownego z podmiotem leczniczym zależy nie tylko od uwarunkowań formalnoprawnych, ale także od czynników pozaprawnych, do których należy zaliczyć życzliwość i poczucie troski o pacjentów. Wydaje się, że przede wszystkim to umowa o pracę wyznacza wysoki poziom gwarancji realizacji prawa do opieki duszpasterskiej z uwagi na najsilniejszą więź kapelana z placówką leczniczą. Prawo państwowe nie określa zakresu obowiązków osób duchownych w zakresie statusu kapelana. Jest to zrozumiałe, biorąc pod

69 Http://www.archidiecezja.katowice.pl/dokumenty/8079-status-kapelana-szpitalnego-w-archidiecezji-katowickiej [dostęp: 5.12.2017]. 
uwagę specyfikę rodzaju pracy. Stosunek prawny kapelana z podmiotem leczniczym jedynie w sposób ramowy określa zakres jego obowiązków. Szczegółowe kierunki działań kapelana wynikają już z prawa kościelnego. Brak jednoznacznego ukształtowania statusu kapelana w prawie państwowym wymaga zmiany w kierunku umocnienia jego pozycji w podmiotach leczniczych. Nie chodzi tu jedynie o kwestie finansowania, ale także o jak najszersze włączanie duchownych do zespołów terapeutycznych, w myśl potrzeby całościowego otoczenia opieką pacjenta. Wydaje się, że taką pozycję zapewnia przede wszystkim status pracownika podmiotu leczniczego. Stan ducha i ciała pozostają w korelacji i warto o tym zawsze pamiętać. Rola kapelana w podmiotach leczniczych nierzadko wykracza poza wymiar ściśle religijny, gdyż duchowny staje się dość często powiernikiem chorego. Coraz większy udział duchownych w trosce o stan psychofizyczny pacjenta wymaga należytego uregulowania statusu kapelana. Podjęcie tych działań w odniesieniu do wszystkich kościołów i innych związków wyznaniowych powinno nastąpić w trybie konsensualnego kształtowania położenia prawnego wspólnot religijnych (art. 25 ust. 4 i 5 Konstytucji). Należy bowiem pamiętać o tym, że troska o dobrostan pacjenta stanowi wspólny cel wspólnoty politycznej i religijnej, wyznaczony dobrem człowieka, co w pełni uzasadnia współdziałanie tych dwóch zbiorowości w kształtowaniu pozycji prawnej kapelana w podmiotach leczniczych.

\section{BIBLIOGRAFIA}

Fąka, Marian. 1978. Państwowe prawo wyznaniowe Polskiej Rzeczypospolitej Ludowej. Wybór tekstów źródłowych. Warszawa: Akademia Teologii Katolickiej.

Florczak, Izabela. 2015. „Granice rozszerzania instytucji prawa pracy na zatrudnienie cywilnoprawne". Folia Iuridica Universitatis Wratislaviensis 4: 237-252.

Jaśkowski, Kazimierz. 2018. „Komentarz aktualizowany do art. 140 Kodeksu pracy”. W: Kazimierz Jaśkowski, Eliza Maniewska, Komentarz aktualizowany do ustawy z dnia 26 czerwca 1974 r. Kodeks pracy (Dz.U.98.21.94). LEX/el.

Krukowski, Józef. 2008. Polskie prawo wyznaniowe. Warszawa: Lexis Nexis.

Maniewska, Eliza. 2016. „Komentarz do art. 84 Kodeksu pracy”. W: Kodeks pracy. Tom I. Komentarz. Ustawy towarzyszace z orzecznictwem. Europejskie prawo pracy z orzecznictwem, Kazimierz Jaśkowski, Eliza Maniewska. Wolters Kluwer, LEX nr 299456. 
Mezglewski, Artur. 2008. „Duszpasterstwa specjalne”. W: Prawo wyznaniowe, Artur Mezglewski, Henryk Misztal, Piotr Stanisz, 200-205. Warszawa: Wydawnictwo C.H. Beck.

Musiała, Anna. 2003. Prawne aspekty wolontariatu. Warszawa: Fundusz Współpracy.

Ożóg, Michał. 2015. „Rejestrowanie kościołów i innych związków wyznaniowych w trybie administracyjnym". Forum Prawnicze 4: 23-40.

Ożóg, Michał. 2016. „Prawo pacjenta do opieki duszpasterskiej w świetle konstytucyjnej zasady równouprawnienia kościołów i innych związków wyznaniowych". Studia z Prawa Wyznaniowego 19: 223-236.

Ożóg, Michał. 2018. „Finansowanie duszpasterstwa specjalnego w podmiotach leczniczych - zarys problemu". W: Kwestie majatkowe w prawie wyznaniowym, 41-66. red. Marek Bielecki. Lublin: Wydawnictwo KUL.

Radwański, Zbigniew, Adam Olejniczak. 2011. Prawo cywilne - część ogólna. Warszawa: Wydawnictwo C.H. Beck.

Ratajczak, Beata. 2002. „Możliwości sprawowania opieki duszpasterskiej w zakładach leczniczych w okresie Polski Ludowej”. Studia z Prawa Wyznaniowego 4: 109-120.

Skąpski, Michał. 2016. „Komentarz do art. 84 Kodeksu pracy”. W: Kodeks pracy. Komentarz. Krzysztof W. Baran (red.), Bolesław Maciej Ćwiertniak, Sławomir Driczinski, Zbigniew Góral, Anna Kosut, Daniel Książek, Wiesław Perdeus, Jan Piątkowski, Michał Skąpski, Krzysztof Stefański, Monika Tomaszewska, Mirosław Włodarczyk, Teresa Wyka. Wolters Kluwer, LEX nr 277598.

Stanisz, Piotr. 2016. „Opieka duszpasterska w szpitalach publicznych państw UE”. Studia z Prawa Wyznaniowego 19: 307-331.

Stefański, Krzysztof. 2016. „Komentarz do art. 140 Kodeksu pracy”. W: Kodeks pracy. Komentarz, Krzysztof W. Baran (red.), Bolesław Maciej Ćwiertniak, Sławomir Driczinski, Zbigniew Góral, Anna Kosut, Daniel Książek, Wiesław Perdeus, Jan Piątkowski, Michał Skąpski, Krzysztof Stefański, Monika Tomaszewska, Mirosław Włodarczyk, Teresa Wyka. Wolters Kluwer, LEX nr 277598.

Strzelecki, Adam. 2012. „Duszpasterstwo wojskowe. Aspekty finansowo-prawne administracji kościelnej”. Studia z zakresu prawa, administracji i zarządzania UKW 1: 99-122.

Wagner, Barbara. 2017. „Komentarz do art. 78 Kodeksu pracy”. W: Kodeks pracy. Komentarz. Ludwik Florek (red.), Dorota Dzienisiuk, Katarzyna Gonera, Grzegorz Goździewicz, Monika Latos-Miłkowska, Łukasz Pisarczyk, Jacek Skoczyński, Joanna Unterschütz, Barbara Wagner, Piotr Wojciechowski, Tadeusz Zieliński. Wolters Kluwer Polska, LEX nr 326346. 
Wałachowska, Monika. 2009. „Komentarz do art. 36”. W: Ustawa o prawach pacjenta i Rzeczniku Praw Pacjenta. Mirosław Nesterowicz (red.), Ewa Bagińska, Marcin Śliwka, Małgorzata Świderska, Monika Wałachowska, 232-233. Warszawa: Instytut Problemów Ochrony Zdrowia.

Zarzycki, Zdzisław. 2014. „Duszpasterstwo w podmiotach leczniczych”. W: Leksykon prawa wyznaniowego. 100 podstawowych pojęć, red. Artur Mezglewski, 84-87. Warszawa: Wydawnictwo C.H. Beck.

\section{CHARACTERIZING THE LEGAL RELATIONSHIP BETWEEN CHAPLAINS AND MEDICAL FACILITIES IN THE CONTEXT OF POLISH LAW AND SELECTED REGULATIONS OF THE ROMAN CATHOLIC CHURCH}

Summary

The aim of this article is to present the legal forms of establishing cooperation between medical facilities and chaplains with a view to guaranteeing patients' right to pastoral care. The main research problem concerns defining the legal relationship between the chaplain and the medical facility in which he provides pastoral care. More specifically, the study aims to characterize the legal relationship between the chaplain and the medical facility taking into account the following types of employment: employment contracts, civil law contracts and voluntary work. The analysis is based on the dogmatic and, to a lesser extent, historical method. The results indicate that employment contracts are especially important in shaping the legal relationship between the chaplain and medical facility. The legal relationship between the chaplain and medical facility is general in character under Polish law owing to the fact that it is necessary to respect the institutional relations between the state and churches and other religious organizations. The specific duties of chaplains are defined by the law of their religious community, which, however, does not automatically apply in Polish law.

Key words: chaplain; churches and other religious organizations; patient; pastoral care; freedom of conscience and religion 